\title{
Automobile Manufacturers, Electric Vehicles and the Price of Oil
}

\author{
Dirk G. Baur* \\ Neda Todorova ${ }^{\dagger}$
}

May 30, 2018

\begin{abstract}
This paper analyzes the oil price sensitivity of the world's largest automobile manufacturers. After controlling for systematic effects we identify a negative oil price sensitivity consistent with a fuel-cost demand effect. This effect has strengthened recently potentially due to the increased popularity of SUVs and despite efforts of major producers to start or increase the production of hybrid and electric vehicles. Tesla is the only company that displays a positive oil price sensitivity consistent with a substitution effect between combustion-engine cars and electric cars.
\end{abstract}

Keywords: Automobile companies; oil prices; electric vehicles; financialization.

JEL classification: G12; G15; L6; Q02

\footnotetext{
*UWA Business School, University of Western Australia, 35 Stirling Highway, Crawley, Perth, WA6018, Australia. E-mail: dirk.baur@uwa.edu.au.

${ }^{\dagger}$ Corresponding author. Griffith Business School, Griffith University, 170 Kessels Road, Nathan QLD 4111, Australia. E-mail: n.todorova@griffith.edu.au.
} 


\section{Introduction}

The question whether oil price changes have a significant impact on the real economy has been subject to active research interest in recent years. Given the importance of oil to the automobile industry, it is surprising that little attention has been devoted to the relationship between the oil market and stock prices of individual manufacturers. The automobile industry is exposed to the dynamics of oil price movements and is facing significant and potentially disruptive changes such as the rise of electric cars, self-driving vehicles and car sharing. Against this backdrop, it is important to understand to what degree equity prices in the automobile industry are linked to oil price changes and how this relation has developed over time. This study analyzes the world's largest carmakers and the electric vehicle manufacturer Tesla Motors and thereby aims to fill a gap in the existing literature.

Several different effects concerning the impact of oil prices on the automobile industry are theoretically possible. First, other things equal, the developments in the oil market may trigger both demand-side as well as supply-side effects in regard to the performance of companies in the automobile industry. On the supply-side, oil price increases may impact the automobile industry by affecting basic production input costs. On the demand-side, an increase in oil prices may cause individuals to drive less or to change demand behavior towards more fuel efficient vehicles. ${ }^{1}$ In terms of recent developments, crude prices crashed from $\$ 115$ barrel in mid-2014 to less than $\$ 30$ in early 2016 (see Figure 1).

This significant change in the price of oil is important as low fuel prices are known to trigger a trend towards SUVs, trucks and bigger cars. The popularity of SUVs and larger vehicles is evidenced by global car sales figures as well as the fact that all large car manufacturers have introduced heavier vehicles in their product range (Bloomberg, 2016c; JATO, 2016; Reuters, 2016). Since higher profit margins are achieved by the sale of larger and more fuel-consuming cars, we hypothesize a negative link between the profitability and market values of automobile manufacturers and oil price levels. ${ }^{2}$

\footnotetext{
${ }^{1}$ Kilian (2008) confirms that in the 1970 s as well as in the 2000s increasing oil prices do induce a shift in demand in favor of fuel efficient cars in the US.

${ }^{2}$ Bloomberg (2016a) reports that larger vehicles enjoy greater customer loyalty as 72 percent of sport utility vehicles owners remained with that vehicle class in 2015, compared to the average car segment loyalty of 62 percent.
} 
Another channel through which the oil price may impact the equity market is related to a global demand effect. The oil price level is generally highly correlated with worldwide industrial production and is known to play a significant role for explaining returns on companies operating in closely related areas such as the oil and gas industry (e.g., Sadorsky, 2001; El-Sharif et al., 2005; Boyer and Filion, 2007). Thus, increasing oil prices may be a signal for the strengthening of global demand and hence be positively associated with equity prices.

Furthermore, a number of factors such as mobility behavior, technological advances and stricter environmental targets around carbon dioxide emissions may change the links between the automobile industry and the oil market.

New mobility services such as car sharing rapidly gain popularity especially in densely populated cities and often involve lighter vehicles. Such services may lead to a decline of private vehicle sales which, however, will be at least partially compensated by increased sales of shared vehicles that need to be replaced more often due to their frequent usage (McKinsey, 2016). In the area of technological breakthroughs, even though the concept of autonomous vehicles is attractive through their long-term potential, the diffusion over the next decade is highly uncertain. However, the rise of electric cars is already a reality with 1.2 million electric cars on the road in 2015 in 40 countries, a steep increase of this figure from 6,000 cars in 2009 (Financial Times, 2016). ${ }^{3}$ A testimony for this development is the involvement of all major car manufacturers in developing hybrid or fully electric cars with the price of lithium-ion battery packs for electric cars experiencing a 65 percent decline since 2010 (Bloomberg, 2016b).

The rise of electric cars fostered by regulations, subsidies and technological advance may induce a shift in demand to environmentally more friendly technologies - a potential substitution effect. On the other hand, if oil experiences a long phase of relatively low or falling prices, it is possible that the demand for electric cars is dampened (Forbes, 2016). Against the backdrop of these developments, it is important for stakeholders to gauge the oil price sensitivity of car manufacturers.

More recently, a number of studies document a pronounced impact of oil prices on stock returns (e.g., Jones and Kaul, 1996; Kilian and Park, 2009; Scholtens and Yurtsever, 2012; Ratti

\footnotetext{
${ }^{3}$ Despite this recent trend, industry reports and the media issue diverging predictions about the market share of electric cars in the future (e.g., Financial Times, 2016; McKinsey, 2016, Bloomberg, 2017).
} 
and Hasan, 2013; Alsalman and Herrera, 2015; Kang et al., 2015; Kaabia et al., 2016; Zhu et al., 2016; Zhang, 2017) and show that the impact is time-varying and largely different across markets and industry sectors (e.g., Elyasiani et al., 2011; Narayan and Sharma, 2011; Degiannakis et al., 2013; Broadstock and Filis, 2014; Broadstock et al., 2015). However, a limited number of studies consider the automotive industry in particular and the evidence is mixed in terms of statistical significance. Using monthly industry-level data from 1973 to 2014, Alsalman (2016) shows that there is a negative relationship between positive oil price innovations and the share prices of automobiles and trucks but the impact is statistically insignificant. Arouri et al. (2011) consider weekly data from 1998 to 2009 and find significant volatility spillovers from the oil market to the US Automobile and Parts industry but not to the corresponding European industry sector. ${ }^{4}$

In addition to sector level studies, there is a stream of papers which analyze individual stocks and subsequently summarize the results across industries. A few of these studies make reference to transportation. Based on daily data from 2000 to 2008 of individual companies listed at the New York Stock Exchange, Narayan and Sharma (2011) document that the transportation sector experiences a rise in returns when oil prices increase. Using US daily data from 1986 to 2010, Phan et al. (2015) find a negative contemporaneous relationship between oil price shocks and the returns of companies from the air and truck transport sub-sectors, and report that the statistical significance at the individual company level is mixed. Broadstock et al. (2016) consider the impact of oil and gasoline prices on individual Chinese companies using weekly data from 2005 to 2012 and report that the automobile industry is affected by oil price shocks, particularly in the long run. One of the fewer studies which reports oil price sensitivity of car manufacturers at the individual firm level is Cameron and Schnusenberg (2009). A Fama-French three-factor model augmented by an oil price factor is applied to daily data of six car manufacturers from March 2001 to September 2008. It is shown that oil prices add value to this asset pricing model especially for manufacturers specializing in pickups and SUVs. This finding is conform to the results of McManus (2007) who suggests that the negative impact of rising fuel prices on vehicle prices is greater for less fuel efficient vehicles than for more fuel efficient vehicles. Cameron and Schnusenberg (2009) conduct a subsample analysis taking into account the impact of the

\footnotetext{
${ }^{4}$ Refer to Broadstock et al. (2016) for a thorough summary of further studies on the relationship between oil price shocks and financial markets.
} 
Iraq invasion in 2003. However, apart from this, the potentially time-varying nature of this relationship for individual car manufacturers has not been discussed extensively.

This study contributes to the existing literature by significantly extending the sample period and the cross-section of automobile companies. Whilst Cameron and Schnusenberg (2009) studied 6 manufacturers over 8 years, this paper analyzes 16 automobile manufacturers over 25 years. We estimate Fama-French three factor models augmented by an oil price factor for daily, weekly and monthly return frequencies, threshold models to distinguish between high and low oil price regimes and time-varying oil price betas to explore systematic changes in oil price sensitivities across automobile companies. The sample includes the world's 15 largest automobile companies in terms of motor vehicle production. Even though the majority of these companies are exploring new technologies or have already introduced hybrid or electric vehicles, their product ranges are a mix of combustion, hybrid and electric vehicles with the latter constituting a small and in most cases negligible proportion only. Thus, the impact of oil markets on electric vehicles cannot be clearly identified using data of these companies. To assess to what extent oil price developments impact electric vehicle manufacturers, the US electric car maker Tesla is included in the analysis. ${ }^{5}$ We hypothesize that Tesla is positively exposed to oil price shocks through a substitution effect between combustion-engine cars and electric cars. If the price of oil increases, the running costs of petrol-powered cars increase and make electric cars more attractive. Similarly, if the price of oil decreases, petrol-powered cars become relatively cheaper than electric cars. Both effects imply a positive oil price exposure of Tesla dependent on the existence of combustion-engine cars as a substitute. Without an alternative based on oil, the conditional oil price sensitivity of Tesla would be zero.

The results provide evidence for the time-varying nature of oil price sensitivities and a strengthening initiated by the Global Financial Crisis in 2008. When systematic risk factors are accounted for, traditional car manufacturers tend to have a negative sensitivity to oil price developments, in line with the notion that increasing oil prices may shift demand towards more environmentally-friendly vehicles and vice versa. Indeed, Tesla's strong positive oil price sensi-

\footnotetext{
${ }^{5}$ Since 2017, the market capitalization of Tesla is on par with the other US car manufacturers such as General Motors and Ford.
} 
tivity suggests that there is a substitution effect in place between traditional cars and electric cars partially driven by the price of oil.

The remainder of this paper is organized as follows. The data and methodology are presented in Section 2. Section 3 presents and discusses the estimation results and section 4 summarizes the main findings and concludes.

\section{Methodology and data}

\section{$2.1 \quad$ Regression models}

The following four-factor regression model is estimated for the excess returns $R_{t}$ of each automobile company (see also Cameron and Schnusenberg, 2009):

$$
R_{t}=\alpha_{0}+\alpha_{1}\left(R_{M, t}-R_{f, t}\right)+\alpha_{2} S M B_{t}+\alpha_{3} H M B_{t}+\beta R_{O i l, t}+\epsilon_{t} .
$$

The excess return on an automobile manufacturer is regressed on the three Fama-French factors (the market risk premium, $R_{M}-R_{f}$, a capitalization factor of small to big firms, $S M B$, a stock valuation factor of high to low book value stocks, $H M L)$ and changes of the oil price. The regression coefficients $\boldsymbol{\alpha}=\left(\alpha_{1}, \alpha_{2}, \alpha_{3}\right)$ and $\beta$ measure the sensitivity of the dependent variable to each of the four factors, respectively. Our main interest is the oil price beta $(\beta)$. The sensitivities in regard to oil price changes estimated according to equation (1) are referred to as conditional whilst unconditional oil price betas are based on a restricted model with $\boldsymbol{\alpha}=0$. We expect $\beta<0$ for traditional car producers due to a fuel-cost effect and $\beta>0$ for electric car producers under the assumption that they benefit from higher oil prices due to a substitution effect of consumers switching from traditional, combustion-engine cars to electric cars.

In a first step, model (1) is applied to the whole data sample. A number of existing papers suggest the existence of structural breaks in the relationship between stock and oil markets (e.g., Sadorsky, 1999, Miller and Ratti, 2009; Broadstock et al., 2015). To investigate the time-varying nature of oil price sensitivities, oil price betas are also estimated based on a 24-month forward rolling window. This approach is an alternative to structural break tests because the adopted rolling estimations can identify and adjust to any structural breaks. 
Furthermore, motivated by the findings of related literature (e.g., Arouri, 2011; Lee and Chiou, 2011; Broadstock et al., 2016) about significant asymmetric effects of oil price shocks on financial markets, a potential dependence of the established relationships on the oil price level is explored by means of a threshold model version,

$$
R_{t}=\alpha_{0}+\alpha_{1}\left(R_{M, t}-R_{f, t}\right)+\alpha_{2} S M B_{t}+\alpha_{3} H M B_{t}+\beta R_{O i l, t}+\beta^{\star} R_{O i l, t} D_{t}+\epsilon_{t},
$$

where the dummy variable $D_{t}$ is equal to one if the price of oil is above a certain threshold and zero otherwise. We consider different thresholds to analyze this effect such as the average oil price over the whole sample period (47US\$), the median price (33US\$) as well as 1-year, and 5 -year moving averages. Model (2) tests statistically for asymmetry based on the coefficient $\beta^{\star}$.

To gain a deeper understanding of the drivers of the oil price betas, we follow previous literature (e.g. Broadstock et al., 2016) and additionally separate oil return series into two parts, one which includes only price increases, $R_{O i l, t}^{+}$, and another including only price decreases, $R_{O i l, t}^{-}$. The model is written as follows:

$$
R_{t}=\alpha_{0}+\alpha_{1}\left(R_{M, t}-R_{f, t}\right)+\alpha_{2} S M B_{t}+\alpha_{3} H M B_{t}+\beta^{+} R_{O i l, t}^{+}+\beta^{-} R_{O i l, t}^{-}+\epsilon_{t} .
$$

This model is particularly interesting and important if positive oil price betas and negative oil price betas have different signs which may result in lower and insignificant average oil betas and thus potentially misleading conclusions.

\subsection{Data}

Table 1 lists the car manufacturers included in this study. In particular, the world's 15 largest automobile companies in terms of motor vehicle production in 2015 are considered along with the electric vehicle manufacturer Tesla. The sample includes a variety of US, Asian and European companies. The analysis spans the period from June 29, 1990 to June 30, 2016. If a company has a shorter price history, the findings are based on the available data (see Table 1 for the exact starting dates of the individual companies). Due to its role as a leading global oil price 
benchmark, daily spot prices per barrel of West Texas Intermediate crude oil are used to calculate oil returns. The data are sourced from Thomson Reuters Datastream.

Since the automobile companies are headquartered in different countries and thus traded on different exchanges with different currencies, daily close-to-close returns may not be perfectly synchronized with the Fama-French factors and changes in the price of oil. To account for this potential problem we predominantly use weekly (Wednesday to Wednesday) returns but also report daily and monthly return estimates for the model specified in equation (1). The threshold and time-varying oil beta models are based on weekly returns only. We use local currency automobile returns and US dollar oil price changes and thus analyze the direct effect of oil price changes for the automobile company in the home market. ${ }^{6}$

The descriptive statistics of the daily returns on the individual companies are shown in Table 1. Tesla stands out with the highest average daily returns and the most volatile returns in the sample. The conducted Ljung-Box tests rule out significant autocorrelations for the daily returns of the considered companies in all cases except Tesla. The statistics also indicate that the returns exhibit fat-tails and GARCH-like properties. We will therefore use heteroscedastic and autocorrelation consistent (HAC) standard errors in all estimations below.

Lastly, daily Fama-French factors and the risk-free rate are obtained from Ken French's website. In order to alleviate potential biases arising from country-specific factors, we use the readily available Global Fama-French factors. This approach ensures consistency and comparability of the findings across the individual companies.

\section{Results}

Figure 1 shows the development of the oil price in the period under consideration, plotted together with a portfolio of equally-weighted returns comprised of the 16 automobile manufacturers. The course of both time series shows that they share common movements especially after the start of the Global Financial Crisis in 2008. This is consistent with the observed finan-

\footnotetext{
${ }^{6}$ The objective of this study is not to analyze the financial performance of a portfolio of automobile companies but the influence of oil price changes on automobile companies.
} 
cialization of the commodity market and the large demand-side impact of the Global Financial Crisis.

\subsection{Full sample: Constant oil price sensitivities}

Table 2 shows estimation results for the four factor model given by equation (1) using daily returns. To account for the potential non-synchronicity of returns and the Fama-French factors, the analysis is repeated using weekly returns (Table 3) and monthly returns (Table 4). The tables also include the R-squares based on the "unconditional" (restricted) model.

The coefficient of the market factor is positive and significant in every regression. Furthermore, $\alpha_{1}$ is often close to one suggesting that automobile manufacturers' stock prices are highly correlated with market returns. The Fama-French factor SMB has changing signs reflecting the differences in the relative size of the individual companies. The Fama-French factor HML is mostly positive indicating that automobile manufacturer companies are primarily "value" companies. An exception is Tesla which, compared to all other companies, shows deviating sensitivities for both SML and HML factors. First, being 1.92 for monthly returns, Tesla's SML sensitivity has the highest magnitude assigning the company to a smaller-cap segment of the market. In fact, as of April 2017, Tesla became the most valuable US automaker in terms of market capitalization. However, the sample period for fitting the four-factor model (1) includes the entire share price history of Tesla since its IPO and thus, a significant portion of the data originates from a period when Tesla was a smaller-cap company. Furthermore, Tesla exhibits a HML factor which is highest in absolute terms among the considered companies and of negative sign $(-2.17$, -1.51 and -1.62 for daily, weekly and monthly returns, respectively). This coefficient confirms that Tesla is regarded by the markets as the company with the highest growth potential.

The oil price sensitivities of individual carmakers exhibit varying significance. The estimated coefficients of the oil price betas are mostly negative, in particular for daily and weekly returns and to a lesser extent for monthly returns. This observation is consistent with the notion that higher oil prices negatively affect the demand for traditional, non-electric automobiles. For longer horizons (monthly returns), oil betas become positive for some firms but are statistically insignificant except for Tesla. The companies with the largest negative oil betas are GM, BMW 
and Daimler. All three companies sell relatively large cars in terms of fuel-consumption. Apparently, GM's Chevy Bolt, BMW's electric car models i3 and i8 and Daimler's Smart represent a too small portion of their car portfolios (and were introduced too late in the sample period) in order to outweigh the strong negative link between the companies' returns and oil price changes arising from the dependence of their revenues on heavier vehicles. ${ }^{7}$

The company that stands out is again Tesla. The pioneer manufacturer of electric vehicles has a weekly oil price sensitivity of 0.27 and 0.48 for monthly returns which is by far the highest among the considered companies. The positive relation to the oil price implies that increased price levels translating into higher fuel prices for combustion vehicles result in stronger interest in electric vehicles, and vice versa. In contrast, Nissan which produces the world's leading electric vehicle model, the Leaf, only exhibits a weekly (monthly) oil price beta of 0.02 (0.06) potentially due to the fact that Nissan has a mixed portfolio of combustion and electric vehicles. Thus, the substitution effect is weaker than in the case of Tesla which focuses on electric vehicles only.

The last and second-last columns of Tables 2 to 4 present the adjusted R-squares values of the full model and a constrained model. It is clear that oil price changes make a negligible contribution to explaining the return development of automobile manufacturers in most cases compared to a full-blown asset pricing model.

\subsection{Time-varying oil price sensitivities}

To enable a better understanding of the time-varying and dynamic relevance of the oil market for the automobile industry, time-varying oil price sensitivities are presented graphically for a restricted (unconditional) model and an unrestricted (conditional) model.

\footnotetext{
${ }^{7}$ An alternative for singling out the role of fuel costs may be to use gasoline or fuel oil prices instead of oil price series, similar to Broadstock et al. (2016) who considered the unique effects of oil price and gasoline price effects on stock returns. We re-estimated the key model (1) with gasoline and fuel oil prices obtained from Datastream (results available upon request). Gasoline and fuel oil prices return series lead to largely very similar results. However, we observe that especially gasoline betas tend to be lower in absolute value compared to the estimated oil betas presented here. This is in line with our expectation. Our study focuses on companies from different countries and is based on one international oil price benchmark for consistency. Using a single gasoline or fuel oil price series originating from one geographical region instead of an international oil price benchmark is likely to lead to less clear-cut insights due to varying taxes and subsidies in different countries. We thank the anonymous Reviewer for this suggestion.
} 


\subsubsection{Unconditional oil betas}

Figure 2 presents oil price betas based on a weekly return frequency and a 24-month forward rolling window obtained with a specification including an intercept and an oil price factor only. The graph shows the evolution of the cross-sectional median, $10 \%$ and $90 \%$ quantiles for each time period. Whilst the oil betas are not consistently different from zero between 1990 and 2008, there is a significant positive change in September 2008 exceeding 0.4 on average and an increased dispersion of oil price betas across firms. For example, median oil price betas are fluctuating around values of 0.3 but the $10 \%$ and $90 \%$ quantiles are around 0 and 0.6 , respectively.

The automobile manufacturer industry exhibits a well-pronounced positive and significant link to the returns on the price of oil during the crisis period and its aftermath. This phenomenon may be a result of a generally increased level of oil price sensitivity of automobile companies. Another reason may be the financialization of commodity markets arising from the increased index investment in commodity markets and resulting in an increased correlation of commodities, particularly oil, and equity markets. To investigate this issue further, in a next step oil price betas are estimated conditional on the Fama-French factors.

\subsubsection{Conditional oil betas}

Figure 3 shows the course of the oil price sensitivities estimated by adding an oil price factor to the conventional Fama-French 3-factor model according to equation (1). Until 2008, most companies' oil betas display a similar evolution as in the unconditional case. However, a change of sign of the oil price betas is observed between 2008 and 2016. This change may be attributed to the increasing informational overlap shared by equity and oil markets which is yet better captured by the conventional equity market related asset pricing factors. Thus, when included in the regression equation, the Fama-French factors absorb a portion of the informational content inherent in oil prices. While oil plays the role of a market proxy in the unconditional case, when the overall market development is taken into account, the estimated coefficient for the oil price uncovers a more clear-cut picture of the dependence of carmakers on the oil price.

During the financial crisis, the results for the individual car manufacturers' oil betas are ambiguous. While some companies exhibit a negative and significant relation to the dynamics 
of the oil price, others have positive or negligible and insignificant oil price betas. The negative oil price betas are potentially due to an increasing focus on large SUV-type vehicles by the majority of car manufacturing companies in the recent years. Interestingly, with oil price betas ranging between -0.15 and -0.2 , even leading manufacturers of eco-friendlier, hybrid vehicles such as Toyota and Nissan, behave similarly to producers of mainly heavier vehicles like Ford and Fiat Chrysler during this period. This suggests that the fuel-cost effect arising from the high profit margin segments of their product portfolios prevails against the (expected) trend towards smaller, environmentally friendlier cars. The negative sensitivity is conform to the study of Cameron and Schnusenberg (2009) who analyze a sample of six companies and find a strong link particularly for SUV-manufacturers.

\subsection{Subsample regression results}

To shed further light onto the strengthened oil price sensitivity since 2008, model (1) is re-run for a subsample period starting with Tesla's IPO (June 29, 2010). The subsample analysis enables a direct comparison of the coefficients of Tesla with other companies for which data are available over longer periods. Hence, their "conditional" oil betas are conditional on the Fama-French asset pricing factors and on the growing hybrid and electric vehicle segment.

The results presented in Table 5 underscore the striking difference between the electric car pioneer Tesla and the other car manufacturers with mixed vehicle portfolios. Tesla exhibits a positive and significant oil price sensitivity of 0.27 that is also the largest oil beta in absolute terms among all companies. The remaining 15 car manufacturers have negative oil price betas and 8 of these are statistically significant at least at the $10 \%$ level. A comparison of the whole sample and subsample oil beta estimates (Tables 3 and 5 , respectively) uncovers that oil price sensitivity has intensified consistently across all automobile companies in the recent years. The increasing importance of oil price changes for car makers in the last 7 years is supported by the higher subsample R-squares compared to the explanatory power documented over the whole sample of 26 years (see the last columns of Tables 3 and 5).

The smallest oil price betas in absolute terms are observed for Hyundai, Nissan, Honda and BMW which all have hybrid or electric vehicles in their portfolios. In contrast, companies such 
as Toyota, Renault and GM, which also manufacture hybrid and electric cars, exhibit strong oil price sensitivities. These differing effects may be due to the fact that EVs and hybrids still represent a small portion in the portfolios of some carmakers as well as different market expectations about future perspectives of individual companies. Some companies may be perceived by the markets as better equipped for a "decarbonized" future and thus be less responsive to oil price risk than others.

Overall, the subsample results corroborate the findings based on the time-varying conditional betas as presented above. The share prices of traditional car manufacturers appear more sensitive to oil price changes possibly because of larger and more fuel-consuming SUVs. An alternative explanation is that consumers and investors display an increased awareness of the existence of substitutes - "cleaner" cars - and thus are more sensitive to oil price changes.

\subsection{Asymmetric reaction to oil price shocks}

\section{Price thresholds}

Since it is possible that the oil price sensitivity varies in different oil price regimes, we first conduct a threshold analysis based on model (2). In order to achieve robust findings, we use different price thresholds, i.e. the mean and the median oil price over the whole sample period as well as time-varying 1-year and 5-year moving-average thresholds. Table 6 presents the estimated conditional oil price betas. The chosen thresholds do not appear to yield any strong evidence for regime-specific differences and asymmetries. Due to these weak findings, we also applied a grid search where we increased stepwise the oil price from its minimum over the whole sample (11 US\$) to its maximum (144 US\$) by increments of one US dollar and used the corresponding values as oil price thresholds. ${ }^{8}$ We find that the number of statistically significant high oil price betas is increasing notably for price thresholds greater than 100 US $\$$ with the majority of high oil price beta coefficients $\beta^{*}$ being negative. However, this result seems to be driven by the extreme oil price movements observed before and after the start of the Global Financial Crisis in the second half of 2008 only.

\footnotetext{
${ }^{8}$ The results are nor tabulated here for the sake of clarity but available upon request.
} 


\section{Return thresholds}

As suggested by previous literature, companies' returns may react differently to positive and negative oil price movements and these effects may thus fully or partially cancel each other out. Therefore, we separate positive and negative oil price movements as per specification (3). Table 7 shows oil price betas for the whole sample (left panel) and the subsample period starting with Tesla's IPO in June 2010 (right panel).

The results indicate that in the full sample period the positive oil price betas and negative oil price betas are not statistically different from each other in most cases. Only three manufactures exhibit a statistically significant asymmetric effect: Toyota, SAIC and Mazda. ${ }^{9}$ Toyota suffers more from negative oil price shocks than it gains from positive oil price shocks which is consistent with the company's significant investments in alternatives to oil such as hybrids. Mazda shows a similar effect as Toyota. In contrast, SAIC gains more from negative oil price shocks than it suffers from positive oil price shocks which is consistent with large cars that consume relatively large amounts of fuel. Interestingly, all three companies exhibit insignificant oil price beta on average (Table 3) but significant oil price betas if positive and negative oil returns are considered separately. This demonstrates the importance of separating (unsigned) oil price betas into positive oil price betas and negative oil price betas.

As documented in Table 5, the oil price sensitivity of automobile companies has intensified since the listing of Tesla. The results for the subsample period 2010-2016 obtained with model (3) suggest that traditional car manufacturers exhibit negative sensitivity to both oil price increases and decreases in the majority of cases during this period. Further analysis (see footnote 9) uncovers that a statistically significant asymmetric effect is given only for Hyundai and SAIC. Hence, significant asymmetric effects can be ruled out for the majority of the world largest carmakers and Tesla.

\footnotetext{
${ }^{9}$ To establish this, we additionally estimate a specification very similar to (3),

$$
R_{t}=\alpha_{0}+\alpha_{1}\left(R_{M, t}-R_{f, t}\right)+\alpha_{2} S M B_{t}+\alpha_{3} H M B_{t}+\beta R_{O i l, t}+\beta^{\star} R_{O i l, t}^{-} D_{t}+\epsilon_{t},
$$

which allows us to test statistically for asymmetric effects by analyzing the statistical significance of the coefficient $\beta^{\star}$. The dummy variable $D_{t}$ equals one if the oil return is negative, and zero otherwise. Results are available upon request.
} 


\section{Summary and concluding remarks}

There has been much speculation about the steep decline of crude oil prices in 2014 and its effect on the real economy. Automobile manufacturers have by nature a high exposure to oil price changes but the impact of the oil market on these companies may be ambiguous. While consumers may react to rising oil prices with fewer purchases due to an increased cost of driving, the automobile industry may also be positively correlated to rising oil prices if it is an indicator of a booming world economy. Additionally, carmakers operate in a dynamic environment facing challenges such as changing mobility behavior, the rise of electric cars and environmental regulations. Against this backdrop, it is important to obtain a profound understanding of the sensitivity of automobile companies towards changes in the price of oil.

The conducted analysis reveals that the oil price sensitivity of automobile manufacturers is time-varying. Whilst relatively weak before 2008, oil price sensitivities strengthened during and after the Global Financial Crisis in 2008. All manufacturers except Tesla have portfolios consisting of both compact and heavier vehicles, and exhibit negative conditional oil price betas indicating that falling oil prices tend to increase stock prices and rising oil prices tend to decrease stock prices. The oil price sensitivity of Tesla is positive and relatively large, i.e. rising oil prices have a positive effect on the share price whilst falling oil prices have a negative effect on the share price. The findings indicate that there is a substitution effect in place between traditional cars and electric cars partially driven by the price of oil. Thus, persisting low oil price levels and higher demand for less fuel efficient cars may not only have adverse environmental consequences but can also dampen the growth potential of electric vehicle manufacturers. 


\section{References}

Alsalman, Z., 2016. Oil price uncertainty and the U.S. stock market analysis based on a GARCHin-mean VAR model. Energy Economics 59, 251-260.

Alsalman, Z., Herrera, A.M., 2015. Oil price shocks and the U.S. stock market: do sign and size matter? Energy Journal 36, 171-188.

Arouri, M.E.D., 2011. Does crude oil move stock markets in Europe? A sector investigation. Economic Modelling 28, 1716-1725.

Arouri, M.E.D., Jouini, J., Nguyen, D.K., 2011. Volatility spillovers between oil prices and stock sector returns: Implications for portfolio management. Journal of International Money and Finance 30, 1387-1405.

Bloomberg, 2016a. Automakers are going All In on SUVs. https://www.bloomberg.com/news/articles/2016-11-16/suv-craze-shows-no-signs-of-slowingas-more-automakers-join-in.

Bloomberg, 2016b. Battery cost plunge seen changing automakers most in 100 years. https://www.bloomberg.com/news/articles/2017-02-02/electric-cars-could-cause-oil-marketdisruption-on-par-with-opec.

Bloomberg, 2016c. China auto sales growth accelerates on rising SUV demand. https://www.bloomberg.com/news/articles/2016-07-08/china-auto-sales-grow-at-fasterpace-on-suv-electric-car-demand.

Bloomberg, 2017. Electric cars could cause big oil this much damage. https://www.bloomberg.com/news/articles/2017-02-02/electric-cars-could-cause-oil-marketdisruption-on-par-with-opec.

Boyer, M.M., Filion, D., 2007. Common and fundamental factors in stock returns of Canadian oil and gas companies. Energy Economics 29, 428-453.

Broadstock, D.C., Cao, H., Zhang, D., 2015. Oil shocks and their impact on energy related stocks in China. Energy Economics 34, 1888-1895. 
Broadstock, D.C., Fan, Y., Ji, Q., Zhang, D., 2016. Shocks and stocks: a bottom-up assessment of the relationship between oil prices, gasoline prices and the returns of Chinese firms. The Energy Journal 37, 55-86.

Broadstock, D.C., Filis, G., 2014. Oil price shocks and stock market returns: New evidence from the United States and China. Journal of International Financial Markets, Institutions \& Money 33, 417-433.

Cameron, K., Schnusenberg, O., 2009. Oil prices, SUVs, and Iraq: An investigation of automobile manufacturer oil price sensitivity. Energy Economics 31, 375-381.

Degiannakis, S., Filis, G., Floros, C., 2013. Oil and stock returns: Evidence from European industrial sector indices in a time-varying environment. Journal of International Financial Markets, Institutions \& Money 26, 175-191.

El-Sharif, I., Brown, D., Burton, B., Nixon, B., Russell, A., 2005. Evidence on the nature and extent of the relationship between oil and equity value in UK. Energy Economics 27, 819-830.

Elyasiani, E., Mansur, I., Odusami, B., 2011. Oil price shocks and industry stock returns. Energy Economics 33, 966-974.

Fama, E.F., French, K.R., 1992. The cross section of expected stock returns. Journal of Finance $47,427-465$.

Financial Times, 2016. Motor industry: Pressure on the pump: Electric cars could make up a quarter of the world's automobiles by 2040. How will it affect oil demand? https://www.ft.com/content/31d68af8-6e0a-11e6-9ac1-1055824ca907.

Forbes, 2016. Cheap gasoline will kill the electric car again. https://www.forbes.com/sites/michaellynch/2016/01/14/will-low-gasoline-prices-whipsawthe-auto-industry-again/2faff7a17175.

JATO, 2016. Global car sales up by $5.6 \%$ in 2016 due to soaring demand in China, India and Europe. http://www.jato.com/global-car-sales-5-6-2016-due-soaring-demand-china-indiaeurope/.

Jones, C.M., Kaul, G., 1996. Oil and the stock markets. Journal of Finance 51, 463-491. 
Kaabia, O., Abid, I., Mkaouar, F., 2016. The dark side of the black gold shock onto Europe: One stock's joy is another stock's sorrow. Economic Modelling 58, 642-654.

Kang, W., Ratti, R.A., Yoon, K.H., 2015. Time-varying effect of oil market shocks on the stock market. Journal of Banking \& Finance 61, S150-S163.

Kilian, L., 2008. The economic effects of energy price ehocks. Journal of Economic Literature 46, 871-909.

Kilian, L., Park, C., 2009. The impact of oil price shocks on the U.S. stock market. International Economic Review 50, 1267-1287.

Lee, Y-H., J-S. Chiou, 2011. Oil sensitivity and its asymmetric impact on the stock market. Energy 36, 168-174.

McKinsey\&Company, 2016. Automotive revolution - perspective towards 2030. How the convergence of disruptive technology-driven trends could transform the auto industry. http://www.mckinsey.com/industries/high-tech/our-insights/disruptive-trends-that-willtransform-the-auto-industry.

McManus, W., 2007. The link between gasoline prices and vehicle sales. Business Economics 42, $53-60$.

Miller, J.I., Ratti, R.A., 2009. Crude oil and stock markets: stability, instability, and bubbles. Energy Economics 31, 559-568.

Narayan, P.K., Sharma, S.S., 2011. New evidence on oil price and firm returns. Journal of Banking \& Finance 35, 3253-3262.

Phan, D.H.B., Sharma, S.S., Narayan, P.K., 2015. Oil price and stock returns of consumers and producers of crude oil. Journal of International Financial Markets, Institutions and Money 34, $245-262$.

PwC, 2016. 2016 Auto industry trends: Automakers and suppliers can no longer sit out the industry's transformation. http://www.strategyand.pwc.com/media/file/2016-Auto-Trends.pdf.

Ratti, R.A., Hasan, M.Z. 2013. Oil price shocks and volatility in Australian stock returns. Economic Record 89, 67-83. 
Reuters, 2016. Japan car makers shuffle output, boost imports to meet U.S. SUV demand. http://www.reuters.com/article/us-autos-japan-suvs-idUSKBN1352AL.

Sadorsky, P., 1999. Oil price shocks and stock market activity. Energy Economics 21, 449-469.

Sadorsky, P., 2001. Risk factors in stock returns of Canadian oil and gas companies. Energy Economics 23, 17-28.

Scholtens, B., Yurtsever, C., 2012. Oil price shocks and European industries. Energy Economics $34,1187-1195$.

Tang, K., Xiong, W., 2012. Index investment and the financialization of commodities. Financial Analysts Journal 68, 54-74.

Tsai, C.-L., 2015. How do U.S. stock returns respond differently to oil price shocks pre-crisis, within the financial crisis, and post-crisis? Energy Economics 50, 47-62.

Zhang, D., 2017. Oil shocks and stock markets revisited: Measuring connectedness from a global perspective. Energy Economics 62, 323-333.

Zhu, H., Guo, Y., You, W., Xu, Y., 2016. The heterogeneity dependence between crude oil price changes and industry stock market returns in China: Evidence from a quantile regression approach. Energy Economics 55, 30-41. 


\section{Appendix: Tables and Figures}

Figure 1: Price of oil and index of automobile companies

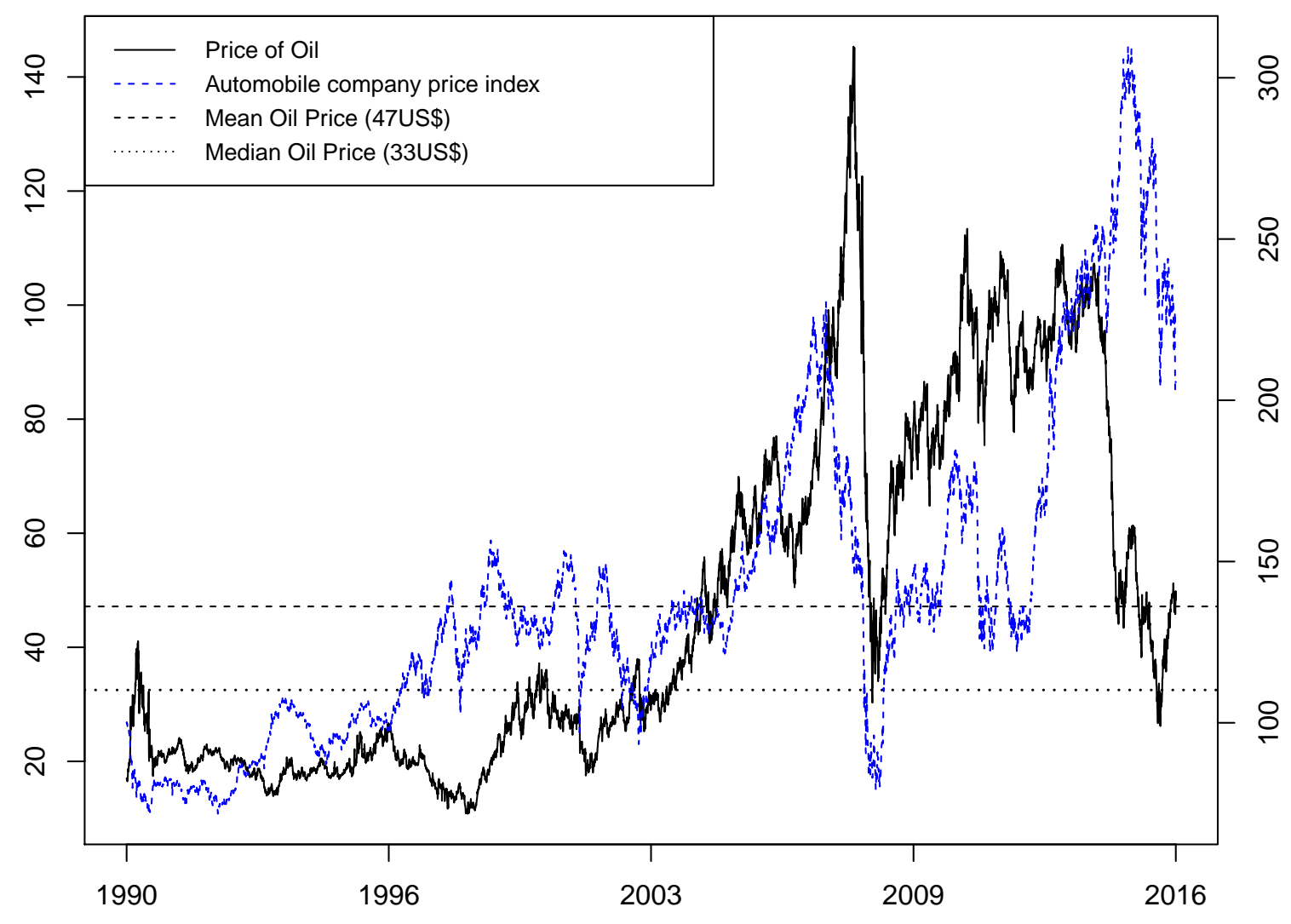


Figure 2: Unconditional 2-year moving average oil price betas (weekly frequency)

The graph shows the $10 \%, 50 \%$ and $90 \%$ quantiles across all 16 automobile companies for each week.

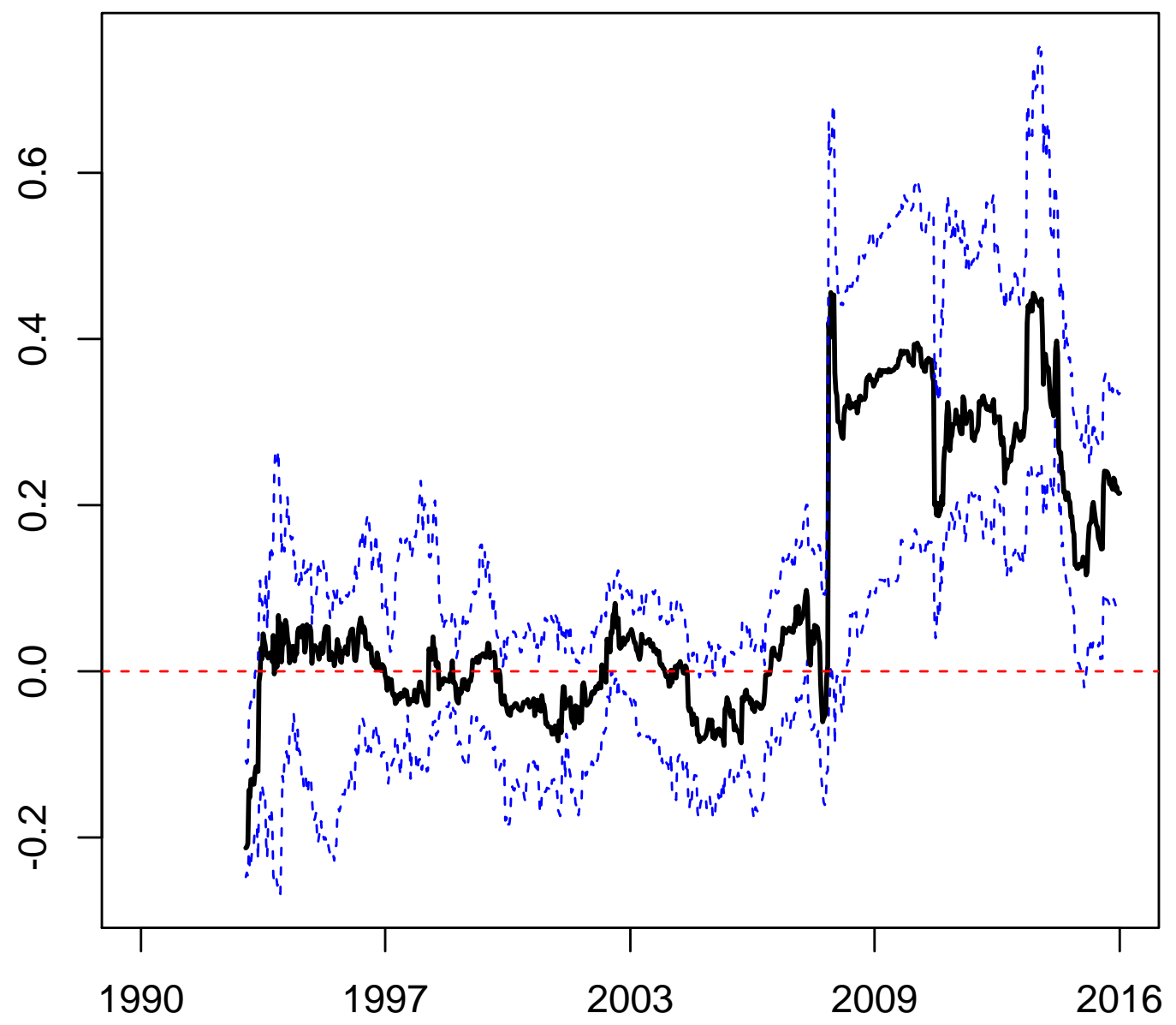


Figure 3: Fama-French conditional 2-year moving average oil price betas (weekly frequency) The graph shows the $10 \%, 50 \%$ and $90 \%$ quantiles across all 16 automobile companies for each week.

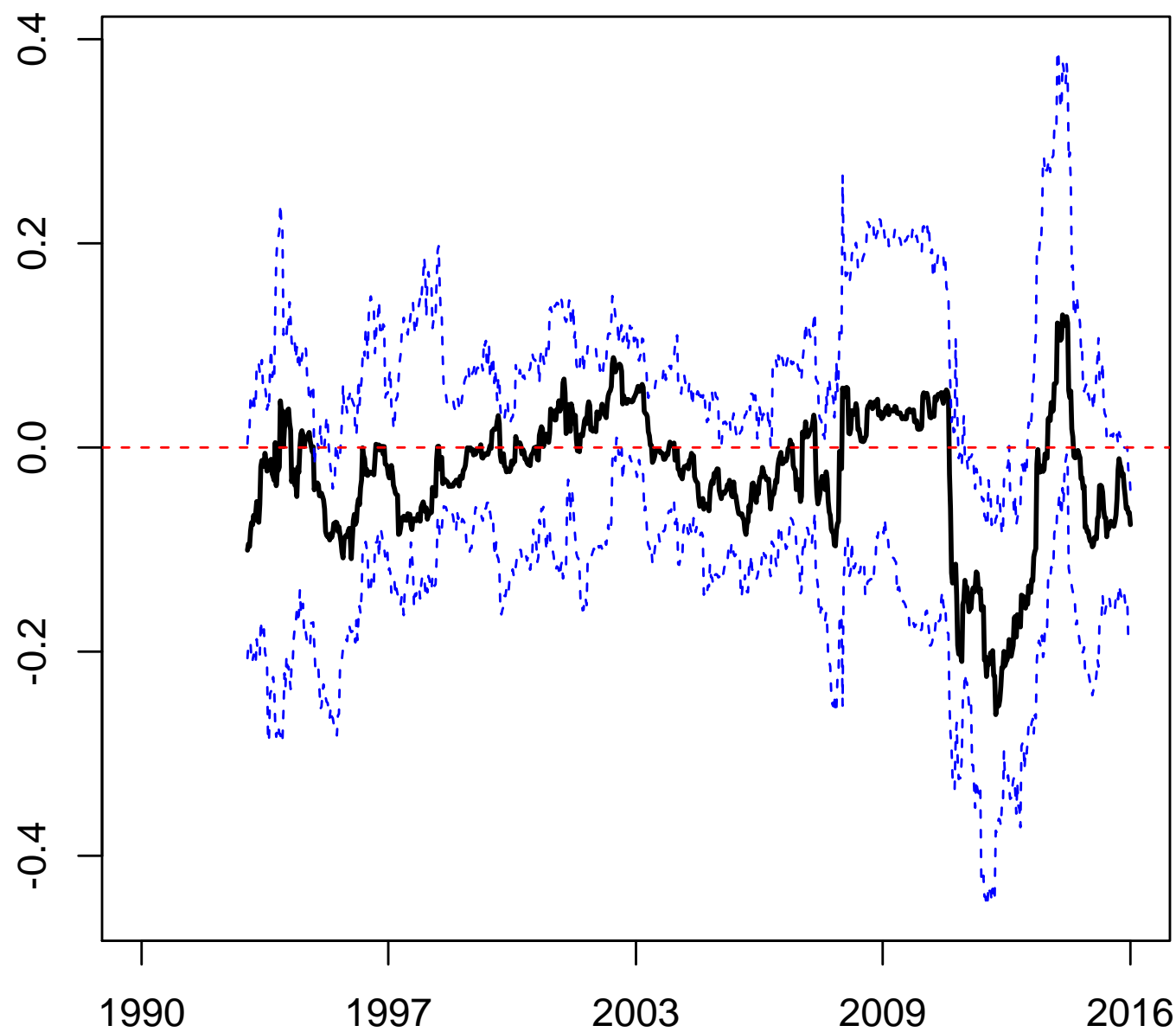


Table 1: Descriptive statistics of daily log returns

\begin{tabular}{lrrrrrrrrr}
\hline & Mean & StDev & Min & Max & Skew & Kurt & LB & Start date & $\mathrm{N}$ \\
\hline Toyota & 0.02 & 1.83 & -12.32 & 14.43 & 0.20 & 7.93 & 0.00 & $29 / 06 / 1990$ & 7,045 \\
Volkswagen & 0.02 & 2.60 & -58.04 & 80.53 & 4.65 & 236.49 & 0.00 & $29 / 06 / 1990$ & 7,045 \\
Hyundai & 0.03 & 2.76 & -16.21 & 18.36 & 0.12 & 7.40 & 0.00 & $29 / 06 / 1990$ & 7,045 \\
General Motors & 0.00 & 1.81 & -11.54 & 9.11 & -0.09 & 6.63 & 0.05 & $18 / 11 / 2010$ & 1,597 \\
Ford & 0.01 & 2.42 & -28.77 & 25.87 & -0.00 & 18.12 & 0.00 & $29 / 06 / 1990$ & 7,045 \\
Nissan & -0.00 & 2.30 & -18.76 & 15.91 & 0.06 & 7.96 & 0.00 & $29 / 06 / 1990$ & 7,045 \\
Fiat Chrysler & -0.00 & 2.38 & -15.73 & 24.00 & 0.19 & 7.14 & 0.08 & $29 / 06 / 1990$ & 7,045 \\
Honda & 0.02 & 2.15 & -15.02 & 16.69 & 0.05 & 8.29 & 0.00 & $29 / 06 / 1990$ & 7,045 \\
Suzuki & 0.02 & 2.30 & -19.40 & 17.14 & 0.08 & 7.93 & 0.00 & $29 / 06 / 1990$ & 7,045 \\
Renault & 0.02 & 2.53 & -15.65 & 15.06 & -0.13 & 6.64 & 0.00 & $17 / 11 / 1994$ & 5,772 \\
Peugeot & 0.00 & 2.27 & -20.05 & 12.93 & -0.11 & 7.09 & 0.00 & $29 / 06 / 1990$ & 7,045 \\
BMW & 0.03 & 1.98 & -15.98 & 13.52 & -0.01 & 7.89 & 0.00 & $29 / 06 / 1990$ & 7,045 \\
SAIC & 0.04 & 2.54 & -40.42 & 9.86 & -0.66 & 18.63 & 0.00 & $25 / 11 / 1997$ & 4,984 \\
Daimler & 0.00 & 2.11 & -14.22 & 17.89 & 0.09 & 8.01 & 0.00 & $26 / 10 / 1998$ & 4,745 \\
Mazda & -0.01 & 2.76 & -20.17 & 22.11 & 0.10 & 7.67 & 0.02 & $29 / 06 / 1990$ & 7,045 \\
Tesla & 0.13 & 3.25 & -21.48 & 21.84 & 0.14 & 9.38 & 0.63 & $29 / 06 / 2010$ & 1,699 \\
Crude Oil & 0.01 & 2.47 & -40.69 & 18.83 & -0.73 & 18.47 & 0.00 & $29 / 06 / 1990$ & 7,045 \\
\hline
\end{tabular}

Note: The column labeled LB shows the p-values of the Ljung-Box test for significant autocorrelations up to lag 10. 
Table 2: Regression results at daily return frequency

\begin{tabular}{|c|c|c|c|c|c|c|}
\hline & MKT & SMB & HML & Oil & $R^{2}$ & $R^{2}$ (oil) \\
\hline Toyota & $\begin{array}{l}0.82^{* * *} \\
(0.0415)\end{array}$ & $\begin{array}{c}0.55^{* * *} \\
(0.0917)\end{array}$ & $\begin{array}{c}0.66^{* * *} \\
(0.083)\end{array}$ & $\begin{array}{c}-0.04^{* * *} \\
(0.01)\end{array}$ & 0.13 & 0.00 \\
\hline Volkswagen & $\begin{array}{c}0.75^{* * *} \\
(0.1299)\end{array}$ & $\begin{array}{c}-0.77^{* *} \\
(0.3847)\end{array}$ & $\begin{array}{c}0.62^{* * *} \\
(0.1958)\end{array}$ & $\begin{array}{c}-0.04^{* *} \\
(0.0173)\end{array}$ & 0.12 & 0.00 \\
\hline Hyundai & $\begin{array}{c}0.69^{* * *} \\
(0.0558)\end{array}$ & $\begin{array}{c}0.61^{* * *} \\
(0.1199)\end{array}$ & $\begin{array}{c}0.04 \\
(0.129)\end{array}$ & $\begin{array}{c}0.00 \\
(0.0158)\end{array}$ & 0.04 & 0.00 \\
\hline General Motors & $\begin{array}{l}1.24^{* * *} \\
(0.0633)\end{array}$ & $\begin{array}{c}-0.48^{* * *} \\
(0.1324)\end{array}$ & $\begin{array}{c}0.27^{*} \\
(0.1449)\end{array}$ & $\begin{array}{l}-0.06^{* *} \\
(0.0229)\end{array}$ & 0.38 & 0.04 \\
\hline Ford & $\begin{array}{c}1.2^{* * *} \\
(0.0596)\end{array}$ & $\begin{array}{c}-0.48^{* * *} \\
(0.1061)\end{array}$ & $\begin{array}{c}0.57^{\text {*** }} \\
(0.1012)\end{array}$ & $\begin{array}{l}-0.04^{* *} \\
(0.0152)\end{array}$ & 0.24 & 0.00 \\
\hline Nissan & $\begin{array}{l}0.94^{* * *} \\
(0.0496)\end{array}$ & $\begin{array}{c}0.79^{* * *} \\
(0.1043)\end{array}$ & $\begin{array}{c}0.59^{* * *} \\
(0.104)\end{array}$ & $\begin{array}{l}-0.03^{* *} \\
(0.0135)\end{array}$ & 0.1 & 0.00 \\
\hline Fiat Chrysler & $\begin{array}{c}1.23^{* * *} \\
(0.044)\end{array}$ & $\begin{array}{c}-0.18^{*} \\
(0.0918)\end{array}$ & $\begin{array}{l}0.94^{* * * *} \\
(0.0821)\end{array}$ & $\begin{array}{c}-0.01 \\
(0.0121)\end{array}$ & 0.24 & 0.01 \\
\hline Honda & $\begin{array}{l}0.87^{* * *} \\
(0.0485)\end{array}$ & $\begin{array}{c}0.57^{* * * *} \\
(0.102)\end{array}$ & $\begin{array}{l}0.55^{* * *} \\
(0.0965)\end{array}$ & $\begin{array}{c}-0.02 \\
(0.0138)\end{array}$ & 0.10 & 0.00 \\
\hline Suzuki & $\begin{array}{c}0.87^{* * *} \\
(0.045)\end{array}$ & $\begin{array}{c}0.47^{* * * *} \\
(0.1011)\end{array}$ & $\begin{array}{c}0.56^{* * *} \\
(0.0997)\end{array}$ & $\begin{array}{c}-0.03^{*} \\
(0.014)\end{array}$ & 0.09 & 0.00 \\
\hline Renault & $\begin{array}{l}1.43^{* * *} \\
(0.0476)\end{array}$ & $\begin{array}{c}-0.43^{* * *} \\
(0.1105)\end{array}$ & $\begin{array}{c}1.01^{* * *} \\
(0.099)\end{array}$ & $\begin{array}{c}-0.01 \\
(0.0134)\end{array}$ & 0.33 & 0.02 \\
\hline Peugeot & $\begin{array}{l}1.17^{* * *} \\
(0.0465)\end{array}$ & $\begin{array}{c}-0.28^{* * *} \\
(0.0845)\end{array}$ & $\begin{array}{c}0.87^{* * *} \\
(0.086)\end{array}$ & $\begin{array}{c}0.01 \\
(0.011)\end{array}$ & 0.25 & 0.01 \\
\hline BMW & $\begin{array}{l}1.08^{* * *} \\
(0.0384)\end{array}$ & $\begin{array}{c}-0.47^{* * *} \\
(0.0862)\end{array}$ & $\begin{array}{c}0.60^{* * *} \\
(0.0807)\end{array}$ & $\begin{array}{c}-0.03^{* * *} \\
(0.0099)\end{array}$ & 0.30 & 0.00 \\
\hline SAIC & $\begin{array}{l}0.28^{* * *} \\
(0.0516)\end{array}$ & $\begin{array}{c}0.37^{* * *} \\
(0.1003)\end{array}$ & $\begin{array}{c}0.14 \\
(0.0848)\end{array}$ & $\begin{array}{c}0.01 \\
(0.0163)\end{array}$ & 0.01 & 0.00 \\
\hline Daimler & $\begin{array}{l}1.23^{* * *} \\
(0.0399)\end{array}$ & $\begin{array}{c}-0.69^{* * *} \\
(0.1047)\end{array}$ & $\begin{array}{l}0.44^{* * *} \\
(0.0803)\end{array}$ & $\begin{array}{c}-0.01 \\
(0.0116)\end{array}$ & 0.43 & 0.03 \\
\hline Mazda & $\begin{array}{l}1.14^{* * *} \\
(0.0646)\end{array}$ & $\begin{array}{c}0.96^{* * *} \\
(0.1276)\end{array}$ & $\begin{array}{c}0.85^{* * *} \\
(0.1096)\end{array}$ & $\begin{array}{c}-0.02 \\
(0.0162)\end{array}$ & 0.10 & 0.00 \\
\hline Tesla & $\begin{array}{c}1.35^{* * *} \\
(0.103) \\
\end{array}$ & $\begin{array}{c}0.07 \\
(0.2678) \\
\end{array}$ & $\begin{array}{c}-2.17^{* * *} \\
(0.2892) \\
\end{array}$ & $\begin{array}{c}0.10^{* *} \\
(0.0379) \\
\end{array}$ & 0.15 & 0.03 \\
\hline
\end{tabular}

Note: The table presents the Fama-French factor estimates and an oil price factor as per model (1) with HAC standard errors (in parentheses). ${ }^{*}\left({ }^{* *},{ }^{* * *}\right)$ denotes the significance at $10 \%(5 \%, 1 \%)$ level. $R^{2}$ presents the goodness of fit for the full model. The $R^{2}$ (oil) denotes the fit of a constrained model with the oil price factor only. 
Table 3: Regression results at weekly return frequency

\begin{tabular}{|c|c|c|c|c|c|c|}
\hline & MKT & SMB & HML & Oil & $R^{2}$ & $R^{2}$ (oil) \\
\hline Toyota & $\begin{array}{c}0.88^{* * *} \\
(0.1058)\end{array}$ & $\begin{array}{c}-0.10 \\
(0.1404)\end{array}$ & $\begin{array}{c}0.13 \\
(0.1688)\end{array}$ & $\begin{array}{c}-0.02 \\
(0.0261)\end{array}$ & 0.27 & 0.01 \\
\hline Volkswagen & $\begin{array}{c}0.52 \\
(0.3792)\end{array}$ & $\begin{array}{c}-0.64^{* * *} \\
(0.1961)\end{array}$ & $\begin{array}{c}0.37^{*} \\
(0.1982)\end{array}$ & $\begin{array}{c}-0.03 \\
(0.0412)\end{array}$ & 0.08 & 0.00 \\
\hline Hyundai & $\begin{array}{c}0.77^{* * *} \\
(0.1229)\end{array}$ & $\begin{array}{c}0.03 \\
(0.3172)\end{array}$ & $\begin{array}{c}0.03 \\
(0.2753)\end{array}$ & $\begin{array}{c}-0.05 \\
(0.0428)\end{array}$ & 0.09 & 0.00 \\
\hline General Motors & $\begin{array}{l}1.34^{* * *} \\
(0.1397)\end{array}$ & $\begin{array}{c}0.18 \\
(0.3985)\end{array}$ & $\begin{array}{c}0.68 \\
(0.4509)\end{array}$ & $\begin{array}{c}-0.13^{*} \\
(0.0703)\end{array}$ & 0.41 & 0.06 \\
\hline Ford & $\begin{array}{c}1.68^{* * *} \\
(0.1988)\end{array}$ & $\begin{array}{c}-0.06 \\
(0.2012)\end{array}$ & $\begin{array}{l}1.19^{\text {*** }} \\
(0.2306)\end{array}$ & $\begin{array}{c}-0.04 \\
(0.0445)\end{array}$ & 0.42 & 0.01 \\
\hline Nissan & $\begin{array}{l}1.08^{* * *} \\
(0.1379)\end{array}$ & $\begin{array}{c}0.36 \\
(0.2133)\end{array}$ & $\begin{array}{c}0.48^{*} \\
(0.2506)\end{array}$ & $\begin{array}{c}0.02 \\
(0.0434)\end{array}$ & 0.24 & 0.02 \\
\hline Fiat Chrysler & $\begin{array}{c}1.49^{* * *} \\
(0.086)\end{array}$ & $\begin{array}{c}0.37 \\
(0.2859)\end{array}$ & $\begin{array}{l}0.79^{* * *} \\
(0.2131)\end{array}$ & $\begin{array}{c}-0.05 \\
(0.0421)\end{array}$ & 0.34 & 0.01 \\
\hline Honda & $\begin{array}{c}0.93^{* * *} \\
(0.1379)\end{array}$ & $\begin{array}{c}0.03 \\
(0.1841)\end{array}$ & $\begin{array}{l}0.47^{* *} \\
(0.178)\end{array}$ & $\begin{array}{c}0.01 \\
(0.0345)\end{array}$ & 0.23 & 0.01 \\
\hline Suzuki & $\begin{array}{c}0.98^{* * *} \\
(0.1135)\end{array}$ & $\begin{array}{c}0.34^{* *} \\
(0.1691)\end{array}$ & $\begin{array}{c}0.38^{*} \\
(0.1921)\end{array}$ & $\begin{array}{c}-0.01 \\
(0.0313)\end{array}$ & 0.24 & 0.01 \\
\hline Renault & $\begin{array}{l}1.69^{* * *} \\
(0.0879)\end{array}$ & $\begin{array}{c}-0.12 \\
(0.2264)\end{array}$ & $\begin{array}{l}0.91^{\text {*** }} \\
(0.1905)\end{array}$ & $\begin{array}{c}-0.02 \\
(0.0378)\end{array}$ & 0.48 & 0.03 \\
\hline Peugeot & $\begin{array}{c}1.32^{* * *} \\
(0.091)\end{array}$ & $\begin{array}{c}-0.10 \\
(0.1566)\end{array}$ & $\begin{array}{c}0.52^{* *} \\
(0.1993)\end{array}$ & $\begin{array}{c}0.04 \\
(0.0391)\end{array}$ & 0.35 & 0.02 \\
\hline BMW & $\begin{array}{l}1.21^{* * *} \\
(0.0698)\end{array}$ & $\begin{array}{c}-0.36^{*} \\
(0.186)\end{array}$ & $\begin{array}{c}0.34^{* *} \\
(0.1604)\end{array}$ & $\begin{array}{l}-0.07^{* *} \\
(0.0267)\end{array}$ & 0.40 & 0.00 \\
\hline SAIC & $\begin{array}{c}0.52^{* * *} \\
(0.106)\end{array}$ & $\begin{array}{c}0.20 \\
(0.223)\end{array}$ & $\begin{array}{l}0.63^{* * *} \\
(0.2018)\end{array}$ & $\begin{array}{c}-0.04 \\
(0.0525)\end{array}$ & 0.06 & 0.00 \\
\hline Daimler & $\begin{array}{l}1.49^{* * *} \\
(0.0947)\end{array}$ & $\begin{array}{c}-0.38^{*} \\
(0.2008)\end{array}$ & $\begin{array}{c}0.00 \\
(0.197)\end{array}$ & $\begin{array}{c}-0.07^{*} \\
(0.0373)\end{array}$ & 0.55 & 0.02 \\
\hline Mazda & $\begin{array}{c}1.23^{* * *} \\
(0.138)\end{array}$ & $\begin{array}{c}0.54^{*} \\
(0.3155)\end{array}$ & $\begin{array}{l}0.91^{* * *} \\
(0.2521)\end{array}$ & $\begin{array}{c}0.04 \\
(0.0458)\end{array}$ & 0.22 & 0.02 \\
\hline Tesla & $\begin{array}{c}0.93^{* * *} \\
(0.2655)\end{array}$ & $\begin{array}{c}1.47 \\
(0.9872)\end{array}$ & $\begin{array}{c}-1.51 \\
(0.9124)\end{array}$ & $\begin{array}{c}0.27^{* *} \\
(0.1318)\end{array}$ & 0.13 & 0.06 \\
\hline
\end{tabular}

Note: The table presents the Fama-French factor estimates and an oil price factor as per model (1) with HAC standard errors (in parentheses). ${ }^{*}\left({ }^{* *},{ }^{* * *}\right)$ denotes the significance at $10 \%(5 \%, 1 \%)$ level. $R^{2}$ presents the goodness of fit for the full model. The $R^{2}$ (oil) denotes the fit of a constrained model with the oil price factor only. 
Table 4: Regression results at monthly return frequency

\begin{tabular}{|c|c|c|c|c|c|c|}
\hline & MKT & SMB & HML & Oil & $R^{2}$ & $R^{2}$ (oil) \\
\hline \multirow[t]{2}{*}{ Toyota } & $0.79^{* * *}$ & $-0.34^{*}$ & 0.17 & 0.01 & 0.23 & 0.01 \\
\hline & $(0.1058)$ & $(0.2011)$ & $(0.2282)$ & $(0.0369)$ & & \\
\hline \multirow{2}{*}{ Volkswagen } & $0.80 * * *$ & -0.44 & $0.55^{*}$ & -0.10 & 0.10 & 0.00 \\
\hline & $(0.2782)$ & $(0.329)$ & $(0.3015)$ & $(0.0854)$ & & \\
\hline \multirow[t]{2}{*}{ Hyundai } & $0.83^{* * *}$ & 0.43 & 0.10 & 0.03 & 0.09 & 0.01 \\
\hline & $(0.1514)$ & $(0.4621)$ & $(0.3901)$ & $(0.065)$ & & \\
\hline \multirow[t]{2}{*}{ General Motors } & $1.76^{* * *}$ & 0.57 & 0.30 & $-0.22^{* *}$ & 0.51 & 0.04 \\
\hline & $(0.3276)$ & $(0.4452)$ & $(0.5643)$ & $(0.0977)$ & & \\
\hline \multirow[t]{2}{*}{ Ford } & $1.52^{* * *}$ & 0.03 & $0.85^{* * *}$ & -0.05 & 0.30 & 0.00 \\
\hline & $(0.1921)$ & $(0.3201)$ & $(0.2698)$ & $(0.072)$ & & \\
\hline \multirow[t]{2}{*}{ Nissan } & $1.01^{* * *}$ & 0.36 & $0.78^{* *}$ & 0.06 & 0.22 & 0.02 \\
\hline & $(0.1552)$ & $(0.2677)$ & $(0.3098)$ & $(0.0612)$ & & \\
\hline \multirow[t]{2}{*}{ Fiat Chrysler } & $1.41^{* * *}$ & $0.58^{*}$ & $0.83^{* * *}$ & -0.02 & 0.29 & 0.01 \\
\hline & $(0.1351)$ & $(0.3075)$ & $(0.2488)$ & $(0.0688)$ & & \\
\hline \multirow[t]{2}{*}{ Honda } & $0.78^{* * *}$ & -0.09 & $0.49 * *$ & 0.00 & 0.17 & 0.01 \\
\hline & $(0.1384)$ & $(0.2334)$ & $(0.241)$ & $(0.0536)$ & & \\
\hline \multirow[t]{2}{*}{ Suzuki } & $0.85^{* * *}$ & 0.34 & 0.14 & 0.04 & 0.21 & 0.02 \\
\hline & $(0.1692)$ & $(0.2636)$ & $(0.2633)$ & $(0.0575)$ & & \\
\hline \multirow[t]{2}{*}{ Renault } & $1.81^{* * *}$ & 0.02 & $1.18^{* * *}$ & -0.03 & 0.45 & 0.03 \\
\hline & $(0.1939)$ & $(0.277)$ & $(0.2418)$ & $(0.0858)$ & & \\
\hline \multirow[t]{2}{*}{ Peugeot } & $1.09 * * *$ & 0.34 & $0.47^{*}$ & 0.04 & 0.23 & 0.02 \\
\hline & $(0.1364)$ & $(0.274)$ & $(0.2553)$ & $(0.0617)$ & & \\
\hline \multirow[t]{2}{*}{ BMW } & $1.26^{* * *}$ & 0.17 & $0.41^{* *}$ & $-0.18^{* * *}$ & 0.37 & 0.00 \\
\hline & $(0.1109)$ & $(0.1998)$ & $(0.2024)$ & $(0.0433)$ & & \\
\hline \multirow[t]{2}{*}{ SAIC } & $0.64^{* *}$ & -0.04 & 0.50 & 0.06 & 0.07 & 0.01 \\
\hline & $(0.2278)$ & $(0.3146)$ & $(0.3199)$ & $(0.0948)$ & & \\
\hline \multirow[t]{2}{*}{ Daimler } & $1.63^{* * *}$ & 0.32 & 0.11 & $-0.19^{* * *}$ & 0.48 & 0.01 \\
\hline & $(0.1424)$ & $(0.3103)$ & $(0.2495)$ & $(0.0566)$ & & \\
\hline \multirow[t]{2}{*}{ Mazda } & $1.41^{* * *}$ & 0.48 & $0.98^{* * *}$ & 0.07 & 0.27 & 0.03 \\
\hline & $(0.2072)$ & $(0.3754)$ & $(0.3247)$ & $(0.0771)$ & & \\
\hline \multirow[t]{2}{*}{ Tesla } & 0.08 & 1.92 & -1.62 & $0.48^{* *}$ & 0.13 & 0.08 \\
\hline & $(0.5144)$ & $(1.2139)$ & $(1.2149)$ & $(0.1911)$ & & \\
\hline
\end{tabular}

Note: The table presents the Fama-French factor estimates and an oil price factor as per model (1) with HAC standard errors (in parentheses). ${ }^{*}\left({ }^{* *},{ }^{* * *}\right)$ denotes the significance at $10 \%(5 \%, 1 \%)$ level. $R^{2}$ presents the goodness of fit for the full model. The $R^{2}$ (oil) denotes the fit of a constrained model with the oil price factor only. 
Table 5: Regression results for subsample period 2010 - 2016 at weekly return frequency

\begin{tabular}{|c|c|c|c|c|c|c|}
\hline & MKT & SMB & HML & Oil & $R^{2}$ & $R^{2}$ (oil) \\
\hline Toyota & $\begin{array}{l}1.01^{* * *} \\
(0.152)\end{array}$ & $\begin{array}{c}0.47 \\
(0.4001)\end{array}$ & $\begin{array}{c}0.52 \\
(0.3969)\end{array}$ & $\begin{array}{c}-0.11^{*} \\
(0.0607)\end{array}$ & 0.29 & 0.04 \\
\hline Volkswagen & $\begin{array}{l}1.49^{* * *} \\
(0.1353)\end{array}$ & $\begin{array}{c}0.02 \\
(0.3852)\end{array}$ & $\begin{array}{c}0.36 \\
(0.4474)\end{array}$ & $\begin{array}{c}-0.12^{*} \\
(0.0649)\end{array}$ & 0.42 & 0.07 \\
\hline Hyundai & $\begin{array}{c}0.59^{* * *} \\
(0.1277)\end{array}$ & $\begin{array}{c}0.50 \\
(0.4144)\end{array}$ & $\begin{array}{l}-0.09 \\
(0.46)\end{array}$ & $\begin{array}{c}-0.02 \\
(0.0584)\end{array}$ & 0.10 & 0.02 \\
\hline General Motors & $\begin{array}{l}1.34^{* * *} \\
(0.1397)\end{array}$ & $\begin{array}{c}0.18 \\
(0.3985)\end{array}$ & $\begin{array}{c}0.68 \\
(0.4509)\end{array}$ & $\begin{array}{c}-0.13^{*} \\
(0.0703)\end{array}$ & 0.41 & 0.06 \\
\hline Ford & $\begin{array}{c}1.44^{* * *} \\
(0.1098)\end{array}$ & $\begin{array}{c}0.47 \\
(0.3209)\end{array}$ & $\begin{array}{c}0.84^{* *} \\
(0.3425)\end{array}$ & $\begin{array}{c}-0.09 \\
(0.0648)\end{array}$ & 0.50 & 0.11 \\
\hline Nissan & $\begin{array}{c}1.11^{* * *} \\
(0.1598)\end{array}$ & $\begin{array}{c}0.65 \\
(0.4575)\end{array}$ & $\begin{array}{c}0.88^{*} \\
(0.4745)\end{array}$ & $\begin{array}{c}-0.05 \\
(0.0675)\end{array}$ & 0.30 & 0.07 \\
\hline Fiat Chrysler & $\begin{array}{c}2.16^{* * *} \\
(0.2184)\end{array}$ & $\begin{array}{c}0.31 \\
(0.6386)\end{array}$ & $\begin{array}{c}0.26 \\
(0.6532)\end{array}$ & $\begin{array}{c}-0.24^{* *} \\
(0.1098)\end{array}$ & 0.43 & 0.05 \\
\hline Honda & $\begin{array}{l}1.16^{* * *} \\
(0.1506)\end{array}$ & $\begin{array}{c}0.62 \\
(0.3934)\end{array}$ & $\begin{array}{c}0.74^{*} \\
(0.4261)\end{array}$ & $\begin{array}{c}-0.08 \\
(0.0642)\end{array}$ & 0.36 & 0.08 \\
\hline Suzuki & $\begin{array}{l}1.12^{* * *} \\
(0.1744)\end{array}$ & $\begin{array}{c}0.73^{*} \\
(0.4197)\end{array}$ & $\begin{array}{l}1.19^{* * *} \\
(0.3941)\end{array}$ & $\begin{array}{c}-0.12^{*} \\
(0.0672)\end{array}$ & 0.32 & 0.06 \\
\hline Renault & $\begin{array}{l}2.04^{* * *} \\
(0.1511)\end{array}$ & $\begin{array}{c}-0.09 \\
(0.488)\end{array}$ & $\begin{array}{c}0.4 \\
(0.5355)\end{array}$ & $\begin{array}{c}-0.17^{*} \\
(0.0888)\end{array}$ & 0.52 & 0.08 \\
\hline Peugeot & $\begin{array}{l}1.99^{* * *} \\
(0.2186)\end{array}$ & $\begin{array}{c}0.77 \\
(0.5579)\end{array}$ & $\begin{array}{c}0.69 \\
(0.6424)\end{array}$ & $\begin{array}{c}-0.15 \\
(0.1017)\end{array}$ & 0.37 & 0.07 \\
\hline BMW & $\begin{array}{c}1.56^{* * *} \\
(0.1218)\end{array}$ & $\begin{array}{c}0.10 \\
(0.3764)\end{array}$ & $\begin{array}{c}-0.27 \\
(0.4115)\end{array}$ & $\begin{array}{c}-0.08 \\
(0.0623)\end{array}$ & 0.53 & 0.09 \\
\hline SAIC & $\begin{array}{c}0.79 * * * \\
(0.2155)\end{array}$ & $\begin{array}{c}-0.17 \\
(0.5638)\end{array}$ & $\begin{array}{c}0.09 \\
(0.5639)\end{array}$ & $\begin{array}{c}-0.15 \\
(0.1325)\end{array}$ & 0.09 & 0.00 \\
\hline Daimler & $\begin{array}{l}1.70^{* * *} \\
(0.1077)\end{array}$ & $\begin{array}{c}0.01 \\
(0.345)\end{array}$ & $\begin{array}{c}-0.10 \\
(0.3004)\end{array}$ & $\begin{array}{c}-0.19^{* * *} \\
(0.0621)\end{array}$ & 0.59 & 0.05 \\
\hline Mazda & $\begin{array}{l}1.73^{* * *} \\
(0.2459)\end{array}$ & $\begin{array}{l}1.61^{* *} \\
(0.678)\end{array}$ & $\begin{array}{l}2.09^{* * *} \\
(0.6757)\end{array}$ & $\begin{array}{l}-0.23^{* *} \\
(0.0949)\end{array}$ & 0.33 & 0.05 \\
\hline Tesla & $\begin{array}{c}0.93^{* * *} \\
(0.2655)\end{array}$ & $\begin{array}{c}1.47 \\
(0.9872)\end{array}$ & $\begin{array}{c}-1.51^{*} \\
(0.9124)\end{array}$ & $\begin{array}{c}0.27^{* *} \\
(0.1318)\end{array}$ & 0.13 & 0.06 \\
\hline
\end{tabular}

Note: The table presents the Fama-French factor estimates and an oil price factor as per model (1) with HAC standard errors (in parentheses). ${ }^{*}\left({ }^{* *},{ }^{* * *}\right)$ denotes the significance at $10 \%(5 \%, 1 \%)$ level. $R^{2}$ presents the goodness of fit for the full model. The $R^{2}$ (oil) denotes the fit of a constrained model with the oil price factor only. The sample period spans the full listing period of Tesla. The results for Tesla are thus equal to the results as presented in Table 3. 


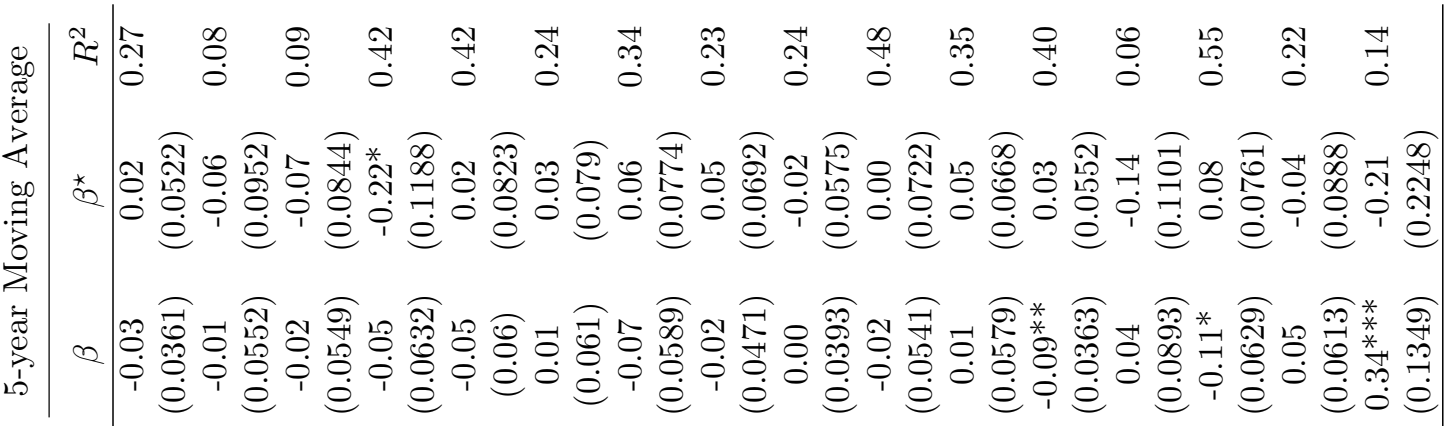

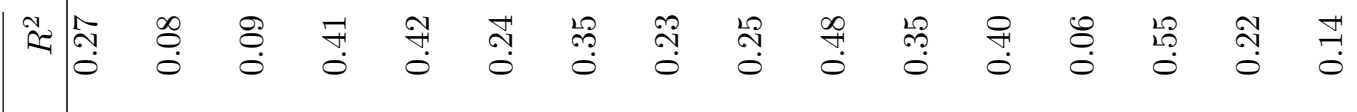

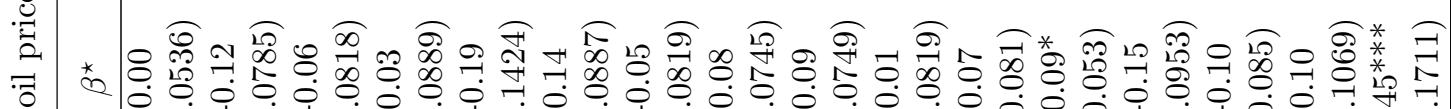
न

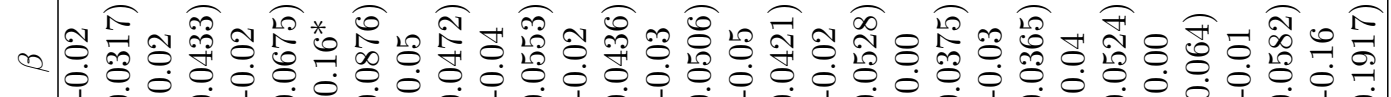

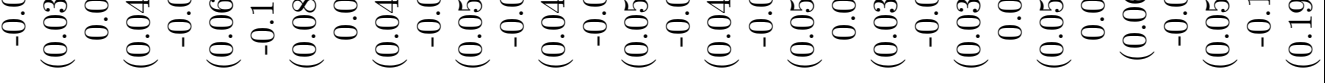

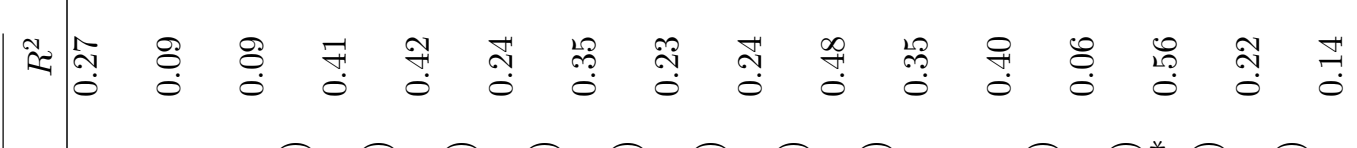

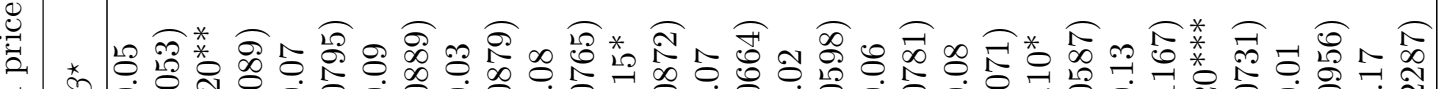

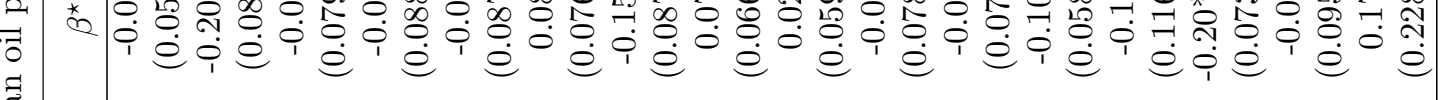

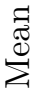

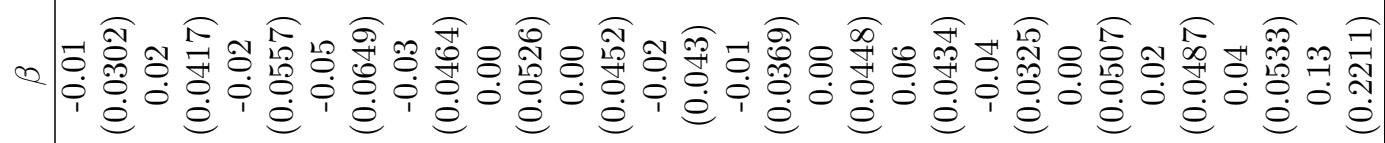


Table 7: Oil betas for the return threshold 0 at weekly frequency

\begin{tabular}{|c|c|c|c|c|c|c|}
\hline & \multicolumn{3}{|c|}{ Full Sample } & \multicolumn{3}{|c|}{ Subsample period $2010-2016$} \\
\hline & $\beta^{+}$ & $\beta^{-}$ & $R^{2}$ & $\beta^{+}$ & $\beta^{-}$ & $R^{2}$ \\
\hline Toyota & $\begin{array}{l}-0.10^{* *} \\
(0.0405)\end{array}$ & $\begin{array}{c}0.04 \\
(0.0448)\end{array}$ & 0.28 & $\begin{array}{c}-0.06 \\
(0.1014)\end{array}$ & $\begin{array}{l}-0.16^{* *} \\
(0.0767)\end{array}$ & 0.29 \\
\hline Volkswagen & $\begin{array}{c}0.02 \\
(0.0808)\end{array}$ & $\begin{array}{c}-0.08 \\
(0.1059)\end{array}$ & 0.08 & $\begin{array}{c}-0.10 \\
(0.0873)\end{array}$ & $\begin{array}{c}-0.15^{*} \\
(0.0895)\end{array}$ & 0.42 \\
\hline Hyundai & $\begin{array}{c}-0.07 \\
(0.072)\end{array}$ & $\begin{array}{c}-0.03 \\
(0.0609)\end{array}$ & 0.09 & $\begin{array}{c}-0.12^{*} \\
(0.0729)\end{array}$ & $\begin{array}{c}0.08 \\
(0.0939)\end{array}$ & 0.11 \\
\hline General Motors & $\begin{array}{c}-0.11 \\
(0.1134)\end{array}$ & $\begin{array}{c}-0.14^{*} \\
(0.0845)\end{array}$ & 0.41 & $\begin{array}{c}-0.11 \\
(0.1134)\end{array}$ & $\begin{array}{c}-0.14^{*} \\
(0.0845)\end{array}$ & 0.41 \\
\hline Ford & $\begin{array}{c}-0.09 \\
(0.0623)\end{array}$ & $\begin{array}{c}0.00 \\
(0.0918)\end{array}$ & 0.42 & $\begin{array}{c}0.14 \\
(0.111)\end{array}$ & $\begin{array}{c}-0.04 \\
(0.0695)\end{array}$ & 0.49 \\
\hline Nissan & $\begin{array}{c}-0.01 \\
(0.0599)\end{array}$ & $\begin{array}{c}0.05 \\
(0.0841)\end{array}$ & 0.24 & $\begin{array}{c}-0.03 \\
(0.0885)\end{array}$ & $\begin{array}{c}-0.07 \\
(0.1023)\end{array}$ & 0.29 \\
\hline Fiat Chrysler & $\begin{array}{c}-0.11^{*} \\
(0.0602)\end{array}$ & $\begin{array}{c}0.01 \\
(0.0685)\end{array}$ & 0.34 & $\begin{array}{c}-0.23^{*} \\
(0.1413)\end{array}$ & $\begin{array}{l}-0.25 \\
(0.171)\end{array}$ & 0.43 \\
\hline Honda & $\begin{array}{c}0.01 \\
(0.0523)\end{array}$ & $\begin{array}{c}0.00 \\
(0.0676)\end{array}$ & 0.23 & $\begin{array}{c}-0.03 \\
(0.0789)\end{array}$ & $\begin{array}{l}-0.14 \\
(0.1)\end{array}$ & 0.36 \\
\hline Suzuki & $\begin{array}{c}-0.07 \\
(0.0506)\end{array}$ & $\begin{array}{c}0.05 \\
(0.0454)\end{array}$ & 0.25 & $\begin{array}{c}-0.08 \\
(0.094)\end{array}$ & $\begin{array}{c}-0.15^{*} \\
(0.0887)\end{array}$ & 0.32 \\
\hline Renault & $\begin{array}{c}-0.03 \\
(0.0638)\end{array}$ & $\begin{array}{c}-0.01 \\
(0.0619)\end{array}$ & 0.48 & $\begin{array}{c}-0.15 \\
(0.1288)\end{array}$ & $\begin{array}{c}-0.20^{*} \\
(0.1159)\end{array}$ & 0.52 \\
\hline Peugeot & $\begin{array}{c}0.01 \\
(0.054)\end{array}$ & $\begin{array}{c}0.06 \\
(0.0676)\end{array}$ & 0.35 & $\begin{array}{c}-0.11 \\
(0.1297)\end{array}$ & $\begin{array}{c}-0.21 \\
(0.1417)\end{array}$ & 0.37 \\
\hline BMW & $\begin{array}{c}-0.07 \\
(0.0458)\end{array}$ & $\begin{array}{c}-0.07^{*} \\
(0.0418)\end{array}$ & 0.40 & $\begin{array}{c}-0.12 \\
(0.0802)\end{array}$ & $\begin{array}{l}-0.05 \\
(0.092)\end{array}$ & 0.54 \\
\hline SAIC & $\begin{array}{c}0.09 \\
(0.1052)\end{array}$ & $\begin{array}{l}-0.16^{* *} \\
(0.0699)\end{array}$ & 0.06 & $\begin{array}{c}0.16 \\
(0.1931)\end{array}$ & $\begin{array}{c}-0.44^{* * *} \\
(0.1216)\end{array}$ & 0.14 \\
\hline Daimler & $\begin{array}{c}-0.10 \\
(0.0656)\end{array}$ & $\begin{array}{c}-0.03 \\
(0.0647)\end{array}$ & 0.55 & $\begin{array}{c}-0.27^{* * *} \\
(0.0795)\end{array}$ & $\begin{array}{c}-0.15 \\
(0.0946)\end{array}$ & 0.60 \\
\hline Mazda & $\begin{array}{c}-0.11 \\
(0.0707)\end{array}$ & $\begin{array}{c}0.16^{* *} \\
(0.0706)\end{array}$ & 0.23 & $\begin{array}{c}-0.32^{* *} \\
(0.1368)\end{array}$ & $\begin{array}{c}-0.17 \\
(0.1451)\end{array}$ & 0.33 \\
\hline Tesla & $\begin{array}{c}0.27 \\
(0.1762) \\
\end{array}$ & $\begin{array}{c}0.27 \\
(0.1908) \\
\end{array}$ & 0.13 & $\begin{array}{c}0.27 \\
(0.1762) \\
\end{array}$ & $\begin{array}{c}0.27 \\
(0.1908) \\
\end{array}$ & 0.13 \\
\hline
\end{tabular}

Note: The table presents the oil price factor estimates with HAC standard errors obtained with the threshold of 0 with model (3). The left panel shows results for the full sample (1990-2016). The right panel shows results the period since Tesla's IPO (June 2010). Tesla and General Motors have the same results in both panels due to their corresponding sample start dates. Fama-French factor estimates are not reported, but available upon request. ${ }^{*}\left({ }^{* *},{ }^{* * *}\right)$ denotes the significance at $10 \%(5 \%, 1 \%)$ level. 


\section{Highlights}

- Study on the oil price sensitivity of the world's largest automobile manufacturers.

- Negative conditional oil betas for traditional carmakers consistent with a fuel-cost effect.

- Significant strengthening of oil price sensitivity since the GFC.

- Tesla shows a strong positive oil price sensitivity.

- Substitution effect between combustion-engine cars and electric cars. 


\section{Accepted Manuscript}

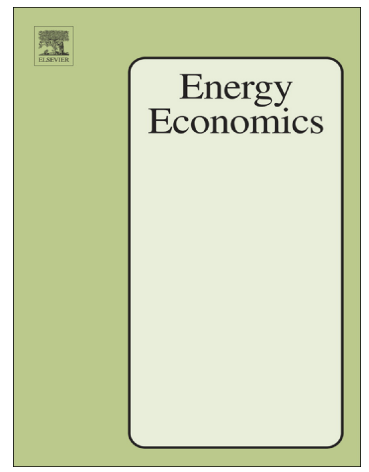

Dirk G. Baur, Neda Todorova

PII:

S0140-9883(18)30207-X

DOI: doi:10.1016/j.eneco.2018.05.034

Reference: ENEECO 4046

To appear in: Energy Economics

Received date: 20 October 2017

Revised date: 14 May 2018

Accepted date: 23 May 2018

Please cite this article as: Dirk G. Baur, Neda Todorova , Automobile Manufacturers, Electric Vehicles and the Price of Oil. Eneeco (2018), doi:10.1016/j.eneco.2018.05.034

This is a PDF file of an unedited manuscript that has been accepted for publication. As a service to our customers we are providing this early version of the manuscript. The manuscript will undergo copyediting, typesetting, and review of the resulting proof before it is published in its final form. Please note that during the production process errors may be discovered which could affect the content, and all legal disclaimers that apply to the journal pertain. 